\title{
Online Learning Evaluation in Higher Education: Study Survey Method
}

\author{
Hengki Wijaya ${ }^{1 *}$, Tri Supartini ${ }^{2}$, Leonard Sumule ${ }^{3}$, Ivan Th. J. Weismann ${ }^{4}$, Ezra Tari ${ }^{5}$ \\ 1,2,3,4Sekolah Tinggi Filsafat Jaffray Makassar, Indonesia, Indonesia \\ ${ }_{5}^{5}$ Pascasarjana Magister Pendidikan Agama Kristen, Institut Agama Kristen Negeri Kupang, Indonesia \\ e-mail: hengkilily1988@gmail.com
}

\section{A R T I CLE IN F O}

\section{Article history:}

Received June 15, 2021

Revised June 17, 2021

Accepted July 20, 2021

Available online August 25, 2021

\section{Kata Kunci:}

Pembelajaran Jarak Jauh

Evaluasi, Online

Keywords:

Distance Learning, Evaluation,

Online

DOI:

http://dx.doi.org/10.23887/jet.v5i 3.35466

\begin{abstract}
A B S T RAK
Tantangan belajar online bagi siswa yaitu kurangnya interaksi secara langsung antara mahasiswa dan dosen menyebabkan mahasiswa kesulitan dalam belajar. Selain itu, kendala jaringan internet yang tidak stabil menyebabkan proses pembelajaran tidak berjalan maksimal. Tulisan ini bertujuan untuk mengevaluasi pembelajaran online di perguruan tinggi. Jenis penelitian yaitu survei deskriptif. Responden penelitian berjumlah 96 mahasiswa. Penelitian ini menguji keefektifan proses belajar online. Data dianalisis dan membandingkan dengan hasil penelitian pada artikel jurnal. Hasil analisis evaluasi pembelajaran online dari sisi siswa pertama menunjukkan bahwa siswa lebih tertarik pada pembelajaran tatap muka daripada online. Kedua, sebagian besar siswa berencana untuk belajar sekarang untuk penggunaan di masa depan. Ketiga, kendala utama yang dihadapi mahasiswa adalah akses internet dan kuota internet. Dosen memiliki peran penting dalam membantu mahasiswa dalam belajar secara online. Ketiga, siswa membutuhkan kelompok untuk saling mengevaluasi selama proses pembelajaran. Dengan demikian, kesiapan dosen dan mahasiswa dalam pembelajaran online perlu ditingkatkan dengan dukungan perangkat teknologi pembelajaran.
\end{abstract}

\section{A B S T R A C T}

The challenge of online learning for students is the lack of direct interaction between students and lecturers, causing students to have difficulty learning. In addition, unstable internet network constraints cause the learning process not to run optimally. This paper aims to develop online learning in universities. The type of research is a descriptive survey. The research respondents were 96 students. This study examines the effectiveness of the online learning process. Data were analyzed and compared with research results in journal articles. The online learning evaluation analysis from the side of the first student showed that students were more interested in face-to-face learning than online. Second, most students plan to study now for future use. Third, the main obstacles faced by students are internet access and internet quota. Lecturers have an essential role in helping students learn online. Third, students need groups to share the happy learning process. Thus, the readiness of lecturers and students in online learning needs to be improved with the support of learning technology devices.

This is an open access article under the $\underline{C C B Y-S A}$ license.

Copyright (C) 2021 by Author. Published by Universitas Pendidikan Ganesha.

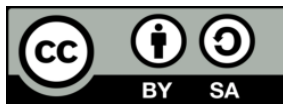

\section{INTRODUCTION}

The Covid-19 pandemic has caused learning activities to turn online (Garad et al., 2021; Syauqi et al., 2020). This is intended to prevent the transmission of Covid-19, which can cause death in humans (Shah et al., 2020; Yulia, 2020). Schools are required to use an online learning system so that students can study at home. This learning system is known as a learning system which means that learning is done online, using learning applications or social networks (Handayani et al., 2021; Ristanto et al., 2020). Online learning systems through personal computers (PCs), laptops, or mobile phones connected to an internet network connection (Khamparia \& Pandey, 2017; D. Zhang et al., 2016). Online learning is done online, but this learning can be done face-to-face with different locations through the conference feature (Aulia et al., 2018; Solehana et al., 2019). All subject matter forms are delivered by the teacher online, and tests are also carried out online. This online learning can be done with several applications such as Google Classroom, Google Meet, Edmudo, and Zoom (Mpungose, 2021; Sadegi, 2019; Widyaningrum et al., 2020). Students have the flexibility of time to study during online learning and can learn anytime and anywhere without being limited by space and time (Solehana et al., 2019; Y. Zhang et al., 2020). Students can also interact with the teacher simultaneously, such as using video calls or live chat. 
Online learning can be provided electronically using forums. Learning online certainly has its challenges. Students need a supportive home atmosphere for learning and an adequate internet connection (Khamparia \& Pandey, 2017; Sayıner \& Ergönül, 2021).

Several universities have implemented online learning in e-learning before the humanitarian disaster of the Covid-19 virus outbreak (Nácher et al., 2021; Sidhu \& Gage, 2021). However, for distance learning, the number is still tiny. When universities are faced with pandemic problems, online learning becomes a trend among lecturers and students. In addition to the use of zoom for classes in Indonesia, zoom is also relevant for distance learning. For example, our lecturer who lives in the United States and for the last three years has been teaching da'wah practice courses through the zoom application with students in Indonesia, especially at the Jaffray College of Philosophy, Makassar, South Sulawesi. The results of the lecturer's observation that online learning can be carried out well. In general, the evaluation criteria include information about learning outcomes (attendance, student grades), student satisfaction, and engagement. An example of the learning process results shows that students who study microeconomic principles online on average get worse scores in macroeconomic principles but do not affect the number of subjects in the economics department (Bosshardt \& Chiang, 2018). Module design related to digital technology offers many opportunities for learning assessment with actionable feedback. The results show $30 \%$ of students prefer combined classes (online and face-to-face) across the curriculum, compared to $47 \%$ of students who prefer hands-on learning. This means that students still like faceto-face learning (Hamilton et al., 2020; Tempelaar, 2019).

Institutions need to prepare training for students, technical support for content development, and delivery methods in online learning to overcome challenges in online education and increase the effectiveness of online teaching and learning (Kebritchi et al., 2017; Rhim \& Han, 2020; Yu, 2021). There are concerns about the quality of interactions between teachers and the campus's underdeveloped technology infrastructure. Thus, internal and external factors influence the application of distance learning technology, such as scope, limited resources, and program evaluation. Previous research found a significant difference between students' learning outcomes attending online and on-campus lectures (Mohr \& Shelton, 2017; Richardson et al., 2016). This means that the higher the student's learning independence, the higher the student's learning outcomes. Based on the Circular of the Secretary-General No. 15 of 2020 concerning guidelines for implementing learning from home. Educators facilitate distance learning online, face-to-face, and a combination of both according to the conditions and availability of learning tools.

Previous research stated that the online learning process can increase the learning satisfaction of nursing students (Tempelaar Chan et al., 2021). Satisfaction is influenced by perceived quality. The method's effectiveness shows that the proposed learning skills can be applied in a learning environment (Beck et al., 2021; Jafari \& Hashim, 2012; Woo et al., 2019). Online information is increasing due to social interactions in online learning spaces (Khamparia \& Pandey, 2017; Rhim \& Han, 2020). The teacher creates a mechanism for communicating with parents and students. Make a lesson plan according to the interests and conditions of students. There are discussions between parents and teachers about inclusive learning plans according to students' conditions. In addition, students have different views on the implementation of online lectures. The model-based online learning process is very effective in the learning process (Alhefnawi, 2021; Syauqi et al., 2020). Poor focus disorders and psychological and management challenges are problems faced in online learning (Maqableh \& Alia, 2021). To increase learning effectiveness, students prefer recording classes with quizzes at the end of each class (Muthuprasad et al., 2021). The purpose of this study is to evaluate online learning at the university level.

\section{METHOD}

The approach in this research uses quantitative research with a survey approach. Sample size and representativeness are two important factors when conducting a survey. Researchers distributed questionnaires to 96 students of the Jaffray Makassar College of Philosophy. Students are selected from the various subjects presented. Interviews are an important part of survey development, one of the most powerful and widely used initial test tools in survey research. This survey was designed with limited information to elicit open and honest responses from participants. The sample size is in two steps, the first is to determine how many additional responses are needed to achieve a suitable sample size based on observations. Second, using the results of a pilot study. The composition of the questionnaire, as well as the contents and words of the objects, were examined. When using open or closed answer questions in a questionnaire.

Researchers working may perform scientific calculations, engage in modelling and simulation, experimental hardware design, analyze data already obtained, and prepare journal articles. This research approach is used to bridge science. Data is collected by filling in the google form. The questionnaire that is distributed is closed because the questions that have been provided in the answer column are the respondents' choices. The data set is made a table using the percentage formula. The percentage results are interpreted and 
grouped based on the evaluations carried out by students as set out in table 1 . The steps used are data collection, assessing structure, and provide a narration of the resulting visual (Decuypere, 2020).

A questionnaire in the form of a statement will be given as many as 15 indicators and 26 items. Questionnaires provide opportunities for students to choose more than one answer. There is also a multiplechoice form. In addition to the questionnaire, the researchers also made observations during the implementation of online learning via Zoom. Research using this population is limited to attitudes and perceptions. Social media data can provide valuable information regarding people's behaviours and health outcomes. Previous studies have shown that social media data can be extracted to monitor and predict infectious disease outbreaks. These same approaches can be applied to other fields including physical activity research and forensic science. Social media data have the potential to provide real-time monitoring and prediction of physical activity level in a given region. This tool can be valuable to public health organizations as it can overcome the time lag in the reporting of physical activity epidemiology data faced by traditional research methods (e.g., surveys, observational studies). As a result, this tool could help public health organizations better mobilize and target physical activity interventions. The first part of this paper aims to describe current approaches (e.g., topic modelling, sentiment analysis and social network analysis) that could be used to analyze social media data to provide real-time monitoring of physical activity level. The second aim of this paper was to discuss ways to apply social media analysis to other fields such as forensic sciences and provide recommendations to further social media research. Class observations, interviews, and scientific journals were used to collect data.

Table 1. Research Instrument Grid

\begin{tabular}{|c|c|}
\hline Aspect of Evaluation & Indicators \\
\hline \multirow{7}{*}{ Student Response to Online learning } & Students' Impressions of Online Learning \\
\hline & The use of applications by lecturers for online learning \\
\hline & Student responses to preferred learning applications \\
\hline & Online learning activities \\
\hline & Online learning fun for students \\
\hline & Constraints faced in online learning \\
\hline & Student responses about future online learning \\
\hline \multirow{7}{*}{$\begin{array}{l}\text { Student Evaluation of Lecturers in } \\
\text { online learning }\end{array}$} & Learning planning (syllabus) for learning subjects \\
\hline & Students' understanding of the material in online learning \\
\hline & Lecturer timeliness in online learning \\
\hline & Mastery of Material by lecturers in online learning \\
\hline & Student feedback in online learning \\
\hline & Mastery of material by students \\
\hline & Lecturers need to be assisted by lecturer assistants in online learning \\
\hline
\end{tabular}

Qualitative data analysis. The percentage of each indicator is the result of research. We then interpreted it into a narrative based on the results listed in the table. Furthermore, the study results are discussed using references to the results of previous studies and the results of a literature review.

\section{RESULT AND DISCUSSION}

\section{Result}

Information collection related to students' impressions of online learning was submitted to 96 respondents. The first question is formulated to determine the impression of students learning online. Students participating in online learning showed a pleasant answer (34.4\%) and more often answered sometimes it was pleasant $(53.1 \%)$. This is due to the habit of students who have studied face-to-face for years and rarely study online using e-learning, let alone online learning. Online learning proves to be very challenging for students who do not have the skills to organize independent learning. However, in virtual classrooms, teachers prefer to refrain from students' online self-presentation. Based on interviews with students who answered the impression "sometimes it is fun" when students do not appear in the practice of preaching. Also, if the learning process is focused on speaking' lectures. The second question is asked to find the application used by the lecturer during online learning. Students may choose more than one answer provided. Student responses who answer applications used by lecturers are shown in table 3. The Zoom meeting application ranks first in student choice, which is $77.1 \%$. The second order is WhatsApp, and the third is Google Classroom. E-learning is only 2\%. This is due to the readiness of lecturers to use the application. And the convenience of students who have installed the 
application via gadgets and laptops. Students use mobile devices in learning for 1 hour. The main activity most students do is accessing the learning slides. Online learning through the WhatsApp platform has several advantages, including ease of use and the development of courage in the discussion process.

In interviews with students, online learning through Zoom provides more views than other applications. Thus, students can still face virtual face-to-face with many friends on one screen. The third question is asked to find learning applications that students like. Students may choose more than one answer provided. The response of students to like the Zoom meeting application (62.5\%). Second place is Google Classroom (52.1\%) and WhatsApp (44.8\%). The top three are student choices considering the ease of meeting face to face online, and the subsequent two applications are to make it easier to collect assignments and answer questions. The use of email is carried out if there are instructions from the lecturer. In this study, lecturers used Zoom meetings more so that students were more familiar with their use. The fourth question is asked to find the form of online learning that students and lecturers are doing. Students may choose more than one answer provided. The student responses can choose more than one answer that they think is appropriate according to the learning activity. The activities of lecturers and students are dominated by direct explanations about the material to be delivered by 83.3\% (80 respondents). $56.3 \%$ of students upload their assignments through online facilities (54 respondents). Students each answered $47.9 \%$ (46 respondents) that the lecturer gave reading assignments and videos and discussed with students.

In this section, lecturers need to use other learning media such as Google Classroom and WhatsApp applications to receive answers from students so that students are active in online learning. The students' answers about whether online learning is fun? Students answered $68.7 \%$ disagreed, and $12.4 \%$ agreed, and 17.7 stated sometimes. This happens during a pandemic. Therefore, lecturers need to be more creative in designing fun online learning. If students are given the opportunity to gather together in the classroom and the lecturer teaches online. Online learning can be fun if the skills of lecturers use other applications to support learning activities. During the Covid-19 pandemic, students complained about the obstacles they faced in online learning. The obstacle for students is that the lack of internet quota $(74 \%)$ can be overcome by providing adequate internet facilities $(34.4 \%)$. If this obstacle is not resolved, students who take online classes will be even lower. Lack of government attention and poor internet infrastructure were identified as significant drivers of adopting the Internet for everything The quality of services, systems, and information has a significant impact on selfadjustment. Adjustment significantly impacts user satisfaction and practical use. Previous schooling and local poverty rates were found to be substantial determinants of overall learning outcomes. These influences vary over time to determine the learning process.

The seventh question is gathering information related to the choice of constraints in online recovery that will be implemented in the future. The students' opinions about online learning in the future. Students answered they disagreed (49\%), and $17.8 \%$ said they agreed to carry out full online learning. $34.4 \%$ expressed doubt. Students' answers are understandable because there is no full institutional support to cover the internet quota. Students prefer blended learning as a future learning solution. The student responses as an evaluation of lecturers in online learning. The lecturer gave information about the learning planning (syllabus) of the learning subjects. As much as $1 \%$ (1 student) answered the lecturer did not explain the syllabus. There were about $9.4 \%$ (9 students) stated that the explanation of the syllabus was unclear. About $46.9 \%$ (45 students) of lecturers explained the syllabus online. As many as $42.7 \%$ of students (41 students) stated that the lecturer explained and posted the syllabus on the internet. The second question is collecting information related to students understanding the learning material presented and explained by the lecturer online. Table 10 shows that students can understand the material presented by the lecturer by $68.8 \%$, and only $10.4 \%$ state that they know the material in online learning. Students' understanding of online learning is supported by learning slide shows and clear lecturer explanations as in face-to-face learning. The answer $16.7 \%$ stated that sometimes it was due to an unstable internet network factor and in and out of online learning applications. Students find that online course materials help them understand class content, stimulating their interest in learning

The third question. What is the timeliness of lecturers in starting and ending online learning? Student assessment of the accuracy of lecturers in online learning stated that it was good $70.8 \%$ and $27.1 \%$ good enough, and only $2.1 \%$ said it was not good ( 2 respondents). Lecturers try to optimize time in online learning because they need to adapt to technological devices and depend on internet speed. The fourth question. The collection of information related to Lecturers mastering the material taught when online learning takes place. Table 12 shows that the lecturer mastered the material in online learning. Students answered $81.3 \%$ that the lecturer mastered according to his expertise. Thus, there are no obstacles for lecturers to convey the material well in online learning. The fifth question, the collection of information related to lecturers, provides an opportunity for students to ask questions during online learning. In table 13, students answered that the lecturer always asked students questions in online learning $(73.2 \%)$. There were $3.1 \%$ who responded that lecturers did not allow students to ask questions. The limited time to complete the teaching materials caused the lecturers do not to have time to open questions to students. 
The sixth question, the collection of information related to Lecturers, provides online feedback on the assignments given. Respondents' answers indicate that students always provide feedback to lecturers in online learning. $47.4 \%$ often give feedback to lecturers. Thus, the process of social interaction between lecturers and students goes well through online learning. Early and frequent feedback facilitates iterative improvements of structure, content, and delivery in virtual spaces. The seventh question is the collection of information related to the material mastered by students. The mastery of the material by students is shown in table 15 . Student answers showed $63.9 \%$ stated that they had mastered the material presented. Only $12.4 \%$ mastered all the material presented. There are $19.6 \%$ who understand a little of the material presented. Online learning provides an opportunity for students to re-learn it because the teaching is usually recorded. The eighth question, information gathering related to the need for lecturers to be assisted by assistants in the online learning process. The results of student responses are shown in table 16. Students answered $19.6 \%$ those lecturers do not need an assistant in online learning. However, $43.3 \%$ answered that lecturers needed assistants in online learning. There were $25.8 \%$ who responded that lecturers needed an assistant in online learning. Lecturer assistants are required to help lecturers prepare digital devices for online learning and disciple teaching assistants to become lecturers in the future.

\section{Discussion}

Based on the results of this study, the author discusses the limitations of students in their readiness to carry out the online learning process. They are familiar with learning technologies such as learning applications such as Zoom meeting, Google Classroom, and WhatsApp. However, they are constrained by the cost of internet quota and social changes shifting rapidly from face-to-face learning to online learning during the pandemic (Rauf et al., 2021; Yulia, 2020). Institutions and the government can overcome this obstacle by automatically providing online learning quotas from the campus academic system. Educational institutions ensure that no student loses education because of location, social class, ethnicity, and so on. Online teaching methods support and facilitate teaching and learning activities, but there is a very urgent need to consider the pros and cons of technology and exploit its potential (McGarr \& Gallchóir, 2021; Purnama et al., 2021; Sert \& Boynueğri, 2017).

Students answered that online learning was not fun required lecturers to find solutions for fun learning models. The learning model can be done in the online learning process. Lecturers think about what models can be used to motivate students to be more involved in online learning. A targeted motivational design model encourages students involved with technology to enhance inquiry-based learning experiences (Aulia et al., 2018; Stockdale et al., 2019). Study attendance is essential to evaluate because it describes the student experience in online and mixed courses that would not be considered (Tsai et al., 2018; Yu, 2021). The Zoom meeting application allows the division of students into smaller groups to discuss and learn together during the online learning process (Mpungose, 2021; Simamora, 2020). Previous research revealed that the ability of a person makes an essential contribution to learning. Therefore, improving student learning outcomes improve soft student skills into online learning (Tseng et al., 2019). However, the results of this study indicate that students who attend face-to-face have more benefits than online learning. However, lecturers need to motivate students to adapt to social changes in the field of digital technology actively and create a fun atmosphere in online learning.

Online learning has several advantages over face-to-face learning. Online learning has a wider reach by watching learning videos and reading material independently (Elfeky \& Masadeh, 2020; Lin et al., 2021). Online learning can be optimally structured to improve the quality of learning through a pretest. Students prioritize learning materials related to classroom learning, namely, learning slides and video lectures are longer and more frequent than other learning materials (namely, shared assignments and posted messages) (Muhammad, 2018; D. Zhang et al., 2016). Students will learn to make choices how to make the learning process better. Online learning experiences have a positive impact on results for achievement. Learning outcomes depend on the amount of experience in the study process (Abosalem, 2016; Syauqi et al., 2020). Online learning is very helpful to improve the skills of the workforce, undergraduate students, regardless of their age, every human being can participate to improve skills and knowledge about new technology and talented people can also participate in a convenient place and time. Learn from online courses (Foldnes, 2016; Tse et al., 2019). Online learning environments encourage learning in more detail with a book, with students being able to restructure and systematize their knowledge.

Each gender group among students can increase positive attitudes in social media and academic achievement (Wu \& Cheng, 2019). In searching for sources of information on the Internet, students demonstrate an increased ability to research the origins of a website, critique evidence, and find reputable sources (McGrew, 2020). The ability to evaluate online content requires not only thinking about the nature and origin of information, contextual knowledge, and use of multiple sources but functional and critical digital skills and an understanding of the Internet and the digital environment (Polizzi, 2020). Online education provides the benefit of converting out, to learn difficult topics through online lectures in an easy way. A village or place where an institute of learning is not available, where students can study through online education. How to improve the 
quality of students directly improves the quality of the institution. Cooperative and interactive learning strategies are the most effective. Multimedia technology support has a good impact on the learning process (Khan \& Masood, 2015; Majid et al., 2012). Teachers should use academic self-efficacy and learning engagement in online learning. are willing to accept input from students regarding learning evaluation so that student perceptions can change to see the sustainability of online learning in the future.

\section{CONCLUSION}

Students evaluate themselves on the implementation of online learning and assessing lecturers in delivering material in online learning. Student evaluation on the learning system is an obstacle in providing internet quota and adapting face-to-face learning to fully online learning. Lecturers through institutions provide internet facility support for students in online learning. Lecturers improve the quality of online learning by using applications that can make online learning fun and interesting for students. The ongoing pandemic period allows online learning to become a basic need for lecturers and students. Thus, the readiness of lecturers and students in online learning needs to be improved with the support of learning technology devices.

\section{REFERENCES}

Abosalem, Y. (2016). Assessment Techniques and Students' Higher-Order Thinking Skills. International Journal of Secondary Education, 4(1), 1-11. https://doi.org/10.11648/j.ijsedu.20160401.11.

Alhefnawi, M. A. M. (2021). Assessing the Efficacy of Online Handouts and Active Lectures in Learning Outcomes at the Engineering Undergraduate Level. Ain Shams Engineering Journal, 40. https://doi.org/10.1016/j.asej.2021.02.012.

Aulia, E. V., Poedjiastoeti, S., \& Agustini, R. (2018). The Effectiveness of Guided Inquiry-Based Learning Material on Students' Science Literacy Skills. Journal of Physics: Conference Series, 947, 1-7. https://doi.org/10.1088/1742-6596/1088/1/012106.

Beck, E., Goin, M. E., Ho, A., Parks, A., \& Rowe, S. (2021). Critical Digital Literacy as Method for Teaching Tactics of Response to Online Surveillance and Privacy Erosion. Computers and Composition. https://doi.org/10.1016/j.compcom.2021.102654.

Bosshardt, W., \& Chiang. (2018). Evaluating the Effect of Online Principles Courses on Long-Term Outcomes. International Review of Economics Education. https://doi.org/10.1016/j.iree.2018.03.001.

Decuypere, M. (2020). Visual Network Analysis: A Qualitative Method for Researching Sociomaterial Practice. Qualitative Research, 20(1). https://doi.org/10.1177/1468794118816613.

Elfeky, A. I. M., \& Masadeh, T. S. Y. (2020). Advance Organizers in Flipped Classroom Via E-Learning Management System and the Promotion of Integrated Science Process Skills. Thinking Skills and Creativity, 35. https://doi.org/10.1016/j.tsc.2019.100622.

Foldnes, N. (2016). The Flipped Classroom and Cooperative Learning: Evidence from a Randomised Experiment. SAGE Journal, 17(1). https://doi.org/10.1177\%2F1469787415616726.

Garad, A., Al-Ansi, A. M., \& Qamari, I. N. (2021). The Role of E-Learning Infrastructure and Cognitive Competence in Distance Learning Effectiveness during the Covid-19 Pandemic. Cakrawala Pendidikan, 40(1). https://doi.org/10.21831/cp.v40i1.33474.

Hamilton, L. A., Suda, K. J., Heidel, R. E., McDonough, S. L. K., Hunt, M. E., \& Franks, A. S. (2020). The Role of Online Learning in Pharmacy Education: A Nationwide Survey of Student Pharmacists. Currents in Pharmacy Teaching and Learning, 12(6). https://doi.org/10.1016/j.cptl.2020.01.026.

Handayani, D., Elvinawati, E., Isnaeni, I., \& Alperi, M. (2021). Development of Guided Discovery Based Electronic Module for Chemical Lessons in Redox Reaction Materials. International Journal of Interactive Mobile Technologies (IJIM), 15(07), 94. https://doi.org/10.3991/ijim.v15i07.21559.

Jafari, K., \& Hashim, F. (2012). The Effects of Using Advance Organizers on Improving EFL Learners' Listening Comprehension: A Mixed Method Study. System, 40(2). https://doi.org/10.1016/j.system.2012.04.009.

Kebritchi, M., Lipschuetz, A., \& Santiague, L. (2017). Issues and Challenges for Teaching Successful Online Courses in Higher Education. Journal of Educational Technology Systems, 46(1). https://doi.org/10.1177/0047239516661713.

Khamparia, A., \& Pandey, B. (2017). Impact of Interactive Multimedia in E-Learning Technologies: Role of Multimedia in E-Learning. Enhancing Academic Research with Knowledge Management Principles, April, 199-227. https://doi.org/10.4018/978-1-5225-2489-2.ch007.

Khan, F. M. A., \& Masood, M. (2015). The Effectiveness of an Interactive Multimedia Courseware with Cooperative Mastery Approach in Enhancing Higher Order Thinking Skills in Learning Cellular Respiration. Procedia-Social and Behavioral Sciences, 176, 977-984. 
https://doi.org/10.1016/j.sbspro.2015.01.567.

Lin, Y.-N., Hsia, L.-H., \& Hwang, G.-J. (2021). Promoting Pre-Class Guidance and In-Class Reflection: A SQIRC-Based Mobile Flipped Learning Approach to Promoting Students' Billiards Skills, Strategies, Motivation and Self-Efficacy No Title. Computers \& Education, 160. https://doi.org/10.1016/j.compedu.2020.104035.

Majid, M. S. Z. B. A., Ali, M. M. B. A., Rahim, A. A. B. A., \& Khamis, N. Y. B. (2012). The Development of Technical English Multimedia Interactive Module to Enhance Student Centered Learning (SCL). Procedia - Social and Behavioral Sciences, 67, 345-348. https://doi.org/10.1016/j.sbspro.2012.11.337.

Maqableh, M., \& Alia, M. (2021). Evaluation Online Learning of Undergraduate Students under Lockdown Amidst Covid-19 Pandemic: The Online Learning Experience and Students' Satisfaction. Children and Youth Services Review, 128(1). https://doi.org/10.1016/j.childyouth.2021.106160.

McGarr, O., \& Gallchóir, C. Ó. (2021). Examining Supervising Field Instructors' Reporting and Assessment ff Technology Use by Pre-Service Teachers on School Placement. Computers \& Education, 146. https://doi.org/10.1016/j.compedu.2019.103753.

McGrew, S. (2020). Learning to evaluate: An Intervention in Civic Online Reasoning. Computers and Education, 145. https://doi.org/10.1016/j.compedu.2019.103711.

Mohr, S. C., \& Shelton, K. (2017). Best Practices Framework for Online Faculty Professional Development: A Delphi Study. Online Learning Journal, 21(4). https://doi.org/10.24059/olj.v21i4.1273.

Mpungose, C. B. (2021). Lecturers' Reflections on Use of Zoom Video Conferencing Technology for ELearning at a South African University in the Context of Coronavirus. African Identities. https://doi.org/10.1080/14725843.2021.1902268.

Muhammad, H. M. (2018). Keefektifan Model Pembelajaran Tebak Kata terhadap Hasil Belajar pada Tema 7 "Indahnya Keragaman di Negeriku" Siswa Kelas IV. Mimbar Ilmu, 23(3), 200-207. https://doi.org/10.23887/mi.v23i3.16436.

Muthuprasad, T., Aiswarya, S., Aditya, K. S., \& Jha, G. K. (2021). Students' Perception and Preference for Online Education in India During Covid-19 Pandemic. Social Sciences \& Humanities Open, 3(1). https://doi.org/10.1016/j.ssaho.2020.100101

Nácher, M. J., Badenes-Ribera, L., Torrijos, C., Ballesteros, M. A., \& Cebadera, E. (2021). The Effectiveness of the Gokoan E-Learning Platform in Improving University Students' Academic Performance. Studies in Educational Evaluation, 70. https://doi.org/10.1016/j.stueduc.2021.101026.

Polizzi, G. (2020). Digital Literacy and The National Curriculum For England: Learning from How the Experts Engage with and Evaluate Online Content. Computers and Education, 152. https://doi.org/10.1016/j.compedu.2020.103859.

Purnama, S., Ulfah, M., Machali, I., Wibowo, A., \& Narmaditya, B. S. (2021). Does Digital Literacy Influence Students' Online Risk? Evidence from Covid-19. Heliyon, 7(6). https://doi.org/10.1016/j.heliyon.2021.e07406.

Rauf, R., Wijaya, H., \& Tari, E. (2021). Entrepreneurship Education Based on Environmental Insight: Opportunities and Challenges in the New Normal Era. Cogent Arts \& Humanities, 8(1). https://doi.org/10.1080/23311983.2021.1945756.

Rhim, H. C., \& Han, H. (2020). Teaching Online: Foundational Concepts of Online Learning and Practical Guidelines. Korean Journal of Medical Education, 32(3), 175-183. https://doi.org/10.3946/kjme.2020.171.

Richardson, J. C., Besser, E., Koehler, A., Lim, J. E., \& Strait, M. (2016). Instructors' Perceptions of Instructor Presence in Online Learning Environments. International Review of Research in Open and Distance Learning, 17(4). https://doi.org/10.19173/irrodl.v17i4.2330.

Ristanto, R. H., Rusdi, R., Mahardika, R. D., Darmawan, E., \& Ismirawati, N. (2020). Digital Flipbook Imunopedia (DFI): A Development in Immune System e-Learning Media. International Journal of Interactive Mobile Technologies (IJIM), 14(19), 140-162. https://doi.org/10.3991/ijim.v14i19.16795.

Sadegi, M. (2019). A Shift Ftom Classroom to Distance Learning: Advantages and Limitation. International Journal of Research in English Education ( IJREE), 4(1). https://doi.org/10.29252/ijree.4.1.80.

Sayıner, A. A., \& Ergönül, E. (2021). E-Learning in Clinical Microbiology and Infectious Diseases. Clinical Microbiology and Infection, 28. https://doi.org/10.1016/j.cmi.2021.05.010.

Sert, N., \& Boynueğri, E. (2017). Digital Technology Use by the Students and English Teachers and SelfDirected Language Learning. World Journal on Educational Technology: Current Issues, 9(1), 24. https://doi.org/10.18844/wjet.v9i1.993.

Shah, K., Arfan, M., Mahariq, I., Ahmadian, A., Salahshour, S., \& Ferrara, M. (2020). Fractal-Fractional Mathematical Model Addressing the Situation of Corona Virus in Pakistan. Results in Physics, 19, 103560. https://doi.org/10.1016/j.rinp.2020.103560.

Sidhu, R., \& Gage, W. H. (2021). Enhancing The Odds of Adopting E-Learning or Community-Focused 
Experiential Learning as a Teaching Practice Amongst University Faculty. Heliyon, 7(4). https://doi.org/10.1016/j.heliyon.2021.e06704.

Simamora, R. M. (2020). The Challenges of Online Learning during the COVID-19 Pandemic: An Essay Analysis of Performing Arts Education Students. Studies in Learning and Teaching, 1(2), 86-103. https://doi.org/10.46627/silet.v1i2.38.

Solehana, L., Asrori, A., \& Usman, A. (2019). The Development of E-Learning Teaching Material Based on Edmodo on Basic Competencies of National Integration at Class X of Senior High School. Journal Of Education, Teaching And Learning, 4(2). https://doi.org/10.26737/jetl.v4i2.1914.

Stockdale, J., Hughes, C., Stronge, S., \& Birch, M. (2019). Motivating Midwifery Students to Digitalise Their Enquiry-Based Learning Experiences: An Evaluative Case Study. Studies in Educational Evaluation, 60. https://doi.org/10.1016/j.stueduc.2018.11.006.

Syauqi, K., Munadi, S., \& Triyono, M. B. (2020). Students' Perceptions toward Vocational Education on Online Learning During the Covid-19 Pandemic. International Journal of Evaluation and Research in Education (IJERE), 9(4), 881. https://doi.org/10.11591/ijere.v9i4.20766.

Tempelaar Chan, S. L., Lin, C. C., Chau, P. H., Takemura, N., \& Fung, J. T. C. (2021). Evaluating Online Learning Engagement of Nursing Students. Nurse Education, 104. https://doi.org/10.1016/j.nedt.2021.104985.

Tempelaar, D. (2019). Assessment \& Evaluation in Higher Education Supporting the Less-Adaptive Student: The Role of Learning Analytics, Formative Assessment and Blended Learning. Assessment and Evaluation in Higher Education, 45(4). https://doi.org/10.1080/02602938.2019.1677855.

Tsai, Y., Lin, C., Hong, J., \& Tai, K. (2018). The Effects of Metacognition on Online Learning Interest and Continuance to Learn with Moocs. Computers \& Education, 121. https://doi.org/10.1016/j.compedu.2018.02.011.

Tse, W. S., Choi, L. Y. A., \& Tang, W. S. (2019). Effects Of Video-Based Flipped Class Instruction on Subject Reading Motivation. British Journal of Educational Technology, 50(1), 385-398. https://doi.org/10.1111/bjet.12569.

Tseng, H., Yi, X., \& Yeh, H. T. (2019). Learning-Related Soft Skills among Online Business Students in Higher Education: Grade Level and Managerial Role Differences in Self-Regulation, Motivation, and Social Skill. Computers in Human Behavior, 95. https://doi.org/10.1016/j.chb.2018.11.035.

Widyaningrum, H. K., Hasanudin, C., Fitrianingsih, A., Novianti, D. E., Saddhono, K., \& Supratmi, N. (2020). The Use of Edmodo Apps in Flipped Classroom Learning. How is the Students' Creative Thinking Ability? Ingénierie Des Systèmes d Inf., 25(1), 69-74. https://doi.org/10.18280/isi.250109.

Woo, E. M. W., Serenko, A., \& Chu, S. K. W. (2019). An Exploratory Study of the Relationship Between the Use of the Learning Commons and Students' Perceived Learning Outcomes. Journal of Academic Librarianship, 45(4). https://doi.org/10.1016/j.acalib.2019.05.007.

Wu, J. Y., \& Cheng, T. (2019). Who is Better Adapted in Learning Online within the Personal Learning Environment? Relating Gender Differences in Cognitive Attention Networks to Digital Distraction. Computers and Education, 128. https://doi.org/10.1016/j.compedu.2018.08.016.

Yu, Z. (2021). The Effects of Gender, Educational Level, and Personality on Online Learning Outcomes during The Covid-19 Pandemic. International Journal of Educational Technology in Higher Education, 18(1), 1-17. https://doi.org/10.1186/s41239-021-00252-3.

Yulia. (2020). Online Learning to Prevent the Spread of Pandemic Corona Virus in Indonesia. ETERNAL (English Teaching Journal), 11(1). https://doi.org/10.26877/eternal.v11i1.6068.

Zhang, D., Zhou, L., Briggs, R. O., \& Nunamaker, J. F. (2016). Instructional Video in E-Learning: Assessing the Impact of Interactive Video on Learning Effectiveness. Information and Management, 43(1), 15-27. https://doi.org/10.1016/j.im.2005.01.004.

Zhang, Y., Ghandour, A., \& Shestak, V. (2020). Using Learning Analytics to Predict Students Performance in Moodle LMS. International Journal of Emerging Technologies in Learning. https://doi.org/10.3991/ijet.v15i20.15915. 